\title{
TO THE ISSUE OF ANTHROPOLOGICAL CONTACTS BETWEEN THE POPULATIONS OF THE SRUBNAYAAND ALAKUL CULTURES OF THE LATE BRONZE AGE IN THE SOUTHERN URALS AND WESTERN KAZAKHSTAN STEPPES ${ }^{1}$
}

\author{
Aleksandr A. Khokhlov \\ Samara State University of Social Sciences and Education, Samara, Russian Federation \\ Egor P. Kitov \\ Institute of Ethnology and Anthropology RAS, Moscow, Russian Federation \\ Yulia O. Kapinus \\ Samara State University of Social Sciences and Education, Samara, Russian Federation
}

\begin{abstract}
Introduction. The work focuses on anthropological materials of the border between two areals: the Srubnaya and Alakul cultures of the Bronze Age. New data is based on the burial grounds of the Kozhumberdy type of the Alakul culture from Western Kazakhstan. Methods and materials. The authors compare the craniological series which are formed according to the geographical localization of the monuments and modern archaeological ideas about their cultural interpretation. Analysis. As a result of statistical analysis, the craniological series of the Srubnaya and Alakul cultures are morphologically quite close, but the latter show higher variability of characteristics. More close to each other are samples of female skulls which show that the formation of physical characteristics of these populations occurred on a single anthropological substrate. Initially, carriers of different caucasoid complexes, mainly of steppe origin, and in a small proportion of the uraloid ones took part in the process. The populations of the Srubnaya and Alakul cultures for a long time interacted with each other. This is reflected in the materials of syncretic Srubnaya-Alakul monuments, as well as in the craniological characteristics of the population of these cultural entities. Judging by morphological features of the skulls, the eastern group of the Alakul population also contacted the collectives of the Fedorovo version of the Andronovo culture of Kazakhstan. The participation of any groups of Central Asian origin in the composition of Alakul populations is not denied, but if it took place, it was most likely of a secondary nature due to the incorporation of certain representatives of a foreign population. Results. The results and conclusions of this work should be used in historical reconstructions of the processes of the formation, development and extinction of the Bronze Age archaeological communities in the area of the VolgaUrals and Western Kazakhstan.
\end{abstract}

Key words: anthropology, archaeology, Alakul culture, Srubnaya culture, Bronze Age, Volga-Ural region, Western Kazakhstan, contacts.

Citation. Khokhlov A.A., Kitov E.P., Kapinus Yu.O. To the Issue of Anthropological Contacts Between the Populations of the Srubnaya and Alakul Cultures of the Late Bronze Age in the Southern Urals and Western Kazakhstan Steppes. Vestnik Volgogradskogo gosudarstvennogo universiteta. Seriya 4. Istoriya. Regionovedenie. = Mezhdunarodnye otnosheniya [Science Journal of Volgograd State University. History. Area Studies. International 파 Relations], 2020, vol. 25, no. 4, pp. 65-83. (in Russian). DOI: https://doi.org/10.15688/jvolsu4.2020.4.4 


\title{
К ПРОБЛЕМЕ АНТРОПОЛОГИЧЕСКИХ СВЯЗЕЙ МЕЖДУ НОСИТЕЛЯМИ СРУБНОЙ И АЛАКУЛЬСКОЙ КУЛЬТУР ПОЗДНЕГО ЭТАПА ЭПОХИ БРОНЗЫ В ЮЖНОМ ПРИУРАЛЬЕ И ЗАПАДНОКАЗАХСТАНСКИХ СТЕПЯХ ${ }^{1}$
}

\author{
Александр Александрович Хохлов \\ Самарский государственный социально-педагогический университет, г. Самара, Российская Федерация \\ Егор Петрович Китов \\ Институт этнологии и антропологии им. Н.Н. Миклухо-Маклая РАН, г. Москва, Российская Федерация

\section{Юлия Олеговна Капинус} \\ Самарский государственный социально-педагогический университет, г. Самара, Российская Федерация
}

Аннотация. Введение. В работе рассматриваются антропологические материалы пограничных между собой срубной и алакульской культур эпохи бронзы. Приводятся новые данные по могильникам кожумбердынского типа алакульской культуры Западного Казахстана. Методы и материальл. Сравниваются краниологические серии, которые сформированы согласно географической локализации памятников и современным археологическим представлениям об их культурной интерпретации. Анализ. В результате статистического анализа краниологические серии срубной и алакульской культур морфологически оказались довольно близки, но последние продемонстрировали более высокую вариабельность характеристик. Более близкими друг другу оказались выборки женских черепов, показавшие, что формирование физических особенностей этих популяций происходило на едином антропологическом субстрате. В процессе изначально принимали участие носители разных европеоидных комплексов, в основном степного происхождения, и в небольшой доле уралоидных. Носители срубной и алакульской культур длительно взаимодействовали, что отражается в материалах синкретичных срубно-алакульских памятников, а также в краниологических характеристиках населения этих культурных образований. Восточная группа алакульского населения, судя по морфологическим особенностям черепов, контактировала также с коллективами федоровского варианта андроновской культуры Казахстана. Участие в сложении алакульских популяций каких-либо коллективов среднеазиатского происхождения не отрицается, но если это и было, то, скорее всего, имело второстепенный характер вследствие инкорпорирования отдельных представителей чужеродного населения. Результаты. Результаты и выводы настоящей работы следует использовать при исторических реконструкциях процессов формирования, развития и угасания археологических сообществ бронзового века в ареале Волго-Уралья и Западного Казахстана. Вклад авторов. А.А. Хохлов - составление структуры публикации, анализ источника и осмысление результатов его статистической обработки, общее оформление текста. Е.П. Китов - написание отдельных позиций в тексте, характеристика и географическая локализация групп алакульской культуры на территории Западного Казахстана, проведение статистического анализа, оформление текста согласно требованиям журнала. Ю.О. Капинус - техническая работа с материалом, реставрация черепов, составление таблиц и обработка графиков, подбор используемой литературы.

Ключевые слова: антропология, археология, алакульская культура, срубная культура, эпоха бронзы, Волго-Уралье, Западный Казахстан, контакты.

Цитирование. Хохлов А. А., Китов Е. П., Капинус Ю. О. К проблеме антропологических связей между носителями срубной и алакульской культур позднего этапа эпохи бронзы в Южном Приуралье и западноказахстанских степях // Вестник Волгоградского государственного университета. Серия 4, История. Регионоведение. Международные отношения. - 2020. - Т. 25, № 4. - С. 65-83. - DOI: https://doi.org/10.15688/jvolsu4.2020.4.4

Введение. Две крупные по географическому распространению культуры бронзового века, сосуществовавшие и граничившие между собой в степях Южного Приуралья, срубная и алакульская. Вопросам их генезиса, развития и угасания уделялось много вни- 
мания как в археологических, так и антропологических работах. По обрядовой практике и предметам материальной культуры их происхождение в основном связывали с местными группами населения, проживавшими на территориях Волго-Уралья и западноказахстанских степей в непосредственно предшествовавшее время. Нужно напомнить о точке зрения, согласно которой эти культуры вырастают через покровский (раннесрубный) и петровский (раннеалакульский) этапы на единой потаповско-синташтинской основе [12, с. 87]. В антропологии, помимо участия местных племен в расогенезе срубного и алакульского населения, предлагались варианты влияния и отдаленных популяций, проникавших напрямую или опосредованно из районов Центральной Европы [21; 39], а также инкорпорирования в среду населения этих культурных образований представителей среднеазиатских культур [6; 13; 14]. В пользу западных инноваций могут свидетельствовать и результаты генетических исследований [42], где показано единство населения культуры шнуровой керамики Центральной Европы, синташтинской и срубной культур восточного ареала ее распространения, основанное на показателях половой наследственности, в частности большей представительности в них мужской гаплогруппы «R1a». Однако рассуждать о прямолинейной связи населения центральных и восточных областей Европы в период поздней бронзы большого смысла не имеет. Для этого данных генетики еще явно недостаточно, а гаплогруппа «R1a» в составе носителей срубной культуры Волго-Уралья могла возникнуть и из других источников, в том числе местных [35, с. 63]. К этому следует дополнить, что в составе серии половых гаплогрупп для населения срубной культуры выявлены и другие комбинации, в то числе по женской линии «U5a, H2-6, T2b4» [43], свидетельствующие о его разнокомпонентности, ранее показанной традиционными методами морфологического анализа $[30 ; 33 ; 38$; 40; и др.]. Алакульская группа Западного Казахстана, как и соседняя группа срубной культуры, представлялась неоднородной. Следует сказать о выделении в ее составе черепов так называемого андроновского варианта протоевропеоидного типа, а также более представительного численно средиземноморского (южноевропеоидного), что в свое время вызвало определенные дискуссии относительно происхождения их носителей $[5 ; 6 ; 13]$. Отметим, что черепа из погребений федоровского варианта андроновской культуры представляют именно широколицых европеоидов. За последние годы в антропологических работах чаще звучал тезис о различиях между представителями, с одной стороны, алакульского населения и, с другой, федоровского населения казахстанских степей на уровне рас второго порядка $[7 ; 8 ; 16 ; 26]$.

Сложность взаимодействия этих двух больших культур в Зауралье отражается в условном делении территории на три части в соответствии с местоположением могильников и происходящих из них серий. Так, по данным археологии, в степной южнозауральской группе памятников выделяется три группы погребальных комплексов, различающиеся как географическими, так и культурными параметрами. Первый вариант условно назван северо-восточным; он включает в себя памятники, находящиеся на границе степной и лесостепной полос в среднем течении рек Уй и Караталы-Аят. Второй вариант - центральный - ограничен реками Караталы-Аят на севере и Синташта на юге (основное ядро срубно-алакульской контактной зоны). Третий юго-западный - концентрируется в Оренбуржье и на юге Зауральской Башкирии [2; 3]. Такая же картина подтверждается и данными антропологического анализа. В северной части локализуются серии черепов с максимальной долей уралоидного компонента; в средней - серии, в краниотипе которых наиболее сильно отразилось влияние гиперморфных европеоидов, находящих аналогии в населении срубной культуры Башкирии; в южной части локализовано население алакульской культуры с чертами южных европеоидов $[17 ; 19 ; 20]$.

В нашем внимании главным является вопрос о взаимоотношении коллективов срубной и алакульской культур. Прямым доказательством связей и их контактов служат материалы синкретичных срубно-алакульских археологических памятников, обнаруживаемых в пограничных для этих культурных образований районах. С поступлением новых источников проблема их связи поднимается 
вновь, акцентируется внимание на получении информации о формах, направлениях и интенсивности взаимодействия. Плотность населения, судя по постоянно накапливаемым материалам из ежегодно исследуемых поселений и могильников, особенно в ареале ВолгоУральского региона, была довольно велика. В настоящее время проводится целенаправленная работа по изучению хозяйственно-культурной деятельности носителей срубной и алакульской культур [22; 23; 41; и др.], выявлению механизмов их адаптации к природным условиям и использованию местных ресурсов. Пристальное внимание уделяется проблеме организации добычи руды, в частности в связи с функционированием Мугоджарского горно-металлургического центра $[27 ; 28]$, который контролировался людьми, оставившими памятники так называемого кожумбердынского типа алакульской культуры. Более западная алакульская группа была ориентирована на добычу руды из каргалинских медистых песчаников Южного Урала, которые обеспечивали металлом также население срубной культуры [36]. И именно здесь, в орско-илекском междуречье, чаще обнаруживаются памятники, сочетающие черты срубной и алакульской культур [9; 24]. В антропологии предпринималась попытка выявления связей носителей этих культур на примере рассмотрения краниологических материалов из срубноалакульских погребальных комплексов Восточного Приуралья [19; 20]. Было предложено, что проникшие в Зауралье носители срубной культуры представляли конечный результат длительной метисации между народами разных волго-уральских культур предшествующего времени при доминанте степного европеоидного компонента. В период существования данного населения оно не было генетически замкнутым, а подпитывалось за счет привнесения генов носителей окружающих близких культурных групп, в первую очередь со срубными и алакульскими традициями.

Исходя из современных археологических представлений, мы провели дополнительный анализ имеющихся и вновь поступивших краниологических материалов срубной и алакульской культур на предмет их связи.

Материалы и методы. Материал срубной культуры Волго-Уралья был подробно изу- чен в работах А.А. Хохлова $[29 ; 30 ; 32 ; 33 ;$ и др.]. По результатам исследования в течение нескольких полевых сезонов археологическими отрядами под руководством В.В. Ткачева и С.Ю.Каменского ряда памятников Южного Урала и степей Зауралья, в частности Уральско-Мугоджарского района, были получены новые антропологические материалы алакульской культуры, относимые авторами к особому, кожумбердынскому его варианту. По количеству скелетов суммарный материал довольно весомый. В составе этой серии значительная доля принадлежит индивидам детского возраста. Черепа людей зрелого возраста оказались преимущественно фрагментарными. В результате реставрации удалось воспроизвести 17 объектов. В основном это мозговые коробки и лишь в двух случаях мы имеем сравнительно полные черепа (Казачья Губерля, к. 6; Еленовский, к. 2, п. 3). Индивидуальные и суммарные данные представлены в таблицах 1, 2.

Казачья Губерля (к. 6). Мужской череп в целом довольно крупный, массивный, высокосводный, долихокранный. Лицевой скелет широкий и низкий, мезогнатный по вертикали с прогнатной альвеолярной частью, умеренно профилированный на горизонтальном уровне по древнеевропеоидному масштабу. По комплексу черт череп европеоидный. Определенно можно сказать, что типологически он не относится к южноевропеоидным.

Еленовский. Мужской череп (к. 2, п. 3) массивный, характеризуется большими размерами мозговой коробки, мезокранией, с умеренно широким и средневысоким, клиногнатным по горизонтали и мезогнатным по вертикали лицевым отделом, сильно выступающими в профиль носовыми костями, европеоидный. Другой череп из этого же кургана (Еленовский, к. 2, п. 5 / женский) также сравнительно крупный по размерам мозговой капсулы, но при этом долихокранный, отличается также узким и уплощенным по горизонтали лбом, ослабленным профилем на назомалярном уровне, очень малым фронтомалярным указателем. Морфологически он иной, вероятно с уралоидной примесью.

Уикаттинский I. Оценка черепов могильника возможна в основном по мозговым коробкам. И мужской, и женские по разме- 
рам довольно крупные, по некоторым признакам средние, имеют высокий свод, доминирует долихокрания, горизонтальная профилировка на назомалярном уровне в двух случаях сравнительно резкая (к. 2, п. 3; к. 22, п. 4). Один череп, женский (к. 12, п. 2) предоставляет сведения о структуре лицевого отдела, который является высоким, с относительно высокими орбитами, узким, хорошо выступающим в профиль носом. Черепа этого могильника, несмотря на плохую сохранность, несомненно, европеоидные.

Аралча II. 5 мужских черепов практически все массивные, по размерам довольно крупные и высокие, в основном долихокранные, в одном случае фиксируется мезобрахикрания (к. 9, п. 4). Наблюдается единство выборки в сильном развитии элементов макрорельфа мозговой коробки, прежде всего сосцевидных отростков. Женские черепа по размерным характеристикам мозговых коробок также в основном крупные, с высоким сводом. Имеются и долихокранные, и мезобрахикранные. В общей выборке прослеживаются различные индивидуальные черты, по которым проявляется ее неоднородность.

Анализ. Сопоставляя новые данные с теми, которые были опубликованы прежде по материалам Западного Казахстана (Тастыбутак I, Хабарное и др.), относящимися, по мнению В.В. Ткачева, именно к кожумбердынскому типу, можно сказать, что представительность широколицых массивных европеоидов в целом увеличилась. Необязательно, однако, этих европеоидов относить именно к андроновскому варианту палеоевропеоидного типа. Они в основе другие и в большей степени близки умеренно широколицым и умеренно массивным, долихокранным типам, встречающимся в материалах срубной и других культур Волго-Уральского региона финала средней - начала поздней бронзы (криволукская культурная группа).

Краниологический материал, относящийся к алакульским древностям западного ареала распространения культуры, был ранжирован согласно новой схеме ${ }^{2}$, с учетом его археологической интерпретации и географической приуроченности памятников (табл. 3$)^{3}$.

Группа, относящаяся к алакульскому культурному образованию, включает выбор- ку раннего ее этапа (петровский культурный тип), кожумбердынского типа, а также выборки черепов из синкретичных срубно-алакульских памятников Южного Урала и Зауралья.

Мы провели межгрупповое сопоставление этих краниологических выборок (табл. 3) с другими сериями синхронного времени. Привлечены материалы алакульской культуры лесостепи юго-востока Западной Сибири ${ }^{4}$ [26], федоровского культурного типа Казахстана [8, c. 110,114$]$. Группы срубной культуры представлены черепами из погребений раннего и развитого ее этапов Волго-Уральского региона, которые были сформированы согласно их географическому районированию [33, с. 120-124]. Серии более раннего времени, а именно периодов средней и ранней бронзы, а также других территорий не использованы.

Применен канонический анализ. Произведена статистическая оценка межгруппового сходства путем вычисления квадратов расстояния Махаланобиса с поправкой на численность. Технические операции выполнялись в статистических программах MultiCan [15] и Statistica 12. В основу расчетов были положены средние данные по 14 основным краниологическим признакам для 14 мужских и 11 женских выборок. В базовые показатели программы вложены также стандартные значения среднеквадратических отклонений признаков [4] и матрица внутригрупповых корреляций, рассчитанная И.Г. Широбоковым.

Максимальное количество признаков, по которым ранжируются мужские выборки с достаточно высокой степенью изменчивости, представлено в наборе первых трех канонических векторов (табл. 4). Для построения графика распределения серий мы использовали данные КВ I и КВ III, которые отражают их вариативность по комплексу важных в краниологической диагностике признаков: $1,8,17$, $9,45,51$. В углах графика представлены их комбинации, показывающие в сумме векторные тенденции к проявлению того или иного морфологического комплекса (рис. 1). На графике выборки расположились довольно широко. Центральное, в некоторой степени нейтральное по краниологической динамике положение заняли серии срубной культуры лесостепей Поволжья (№ 11, 12) и Приуралья (№ 9, 13), а также срубно-алакульская культура За- 
уралья (№ 6). Несколько в отдалении оказались выборки Поволжской степи (№ 7, 10). Окраинные позиции заняли петровская (раннеалакульская) выборка (сектор А), срубная приуральская степная (сектор Б), группа в составе кожумбердынской, западной срубноалакульской и покровской Самарского Поволжья $(№ 2,3,8)$ и суммарная серия андроновской / федоровской культуры Казахстана (№ 5). С учетом расстояний Махаланобиса подтвердилась близость между кожумбердынской выборкой и покровской Самарского Поволжья (№ 3-8 // 0,1) ${ }^{5}$, с южноуральской срубно-алакульской (№ 3-2 // 0,2), покровской и срубной Приуралья (№ 9-13 // 0,1), срубниками Поволжской лесостепи и Самаро-Сокского бассейна (№ 11-12 // 0,2), резче обозначилась связь между покровской и срубной степей Поволжья (№ 7-10 // 0,4).

Для построения графика расположения женских выборок (рис. 2) также использованы данные КВ I и КВ III, где наибольшие нагрузки падают на ряд линейных признаков: 1 , $8,17,9,45,51$. Здесь, как и на графике по мужским выборкам, обособленные позиции заняли восточноалакульская (№ 5) и федоровская Казахстана (№ 6). Сравнительно отдельно стоят обе выборки срубной культуры Южного Приуралья (№ 10, 11). Остальные расположились в центральной части довольно компактно. В составе этой группы оказались выборки и срубной культуры Поволжья (№ 7, 9), и алакульской Южного Урала и Казахстана. Следует отметить, что выборки черепов из погребений с алакульскими традициями формируют в некоторой степени самостоятельную подгруппу (№ 1, 2, 3, 4), где прослеживается сближение, как и на мужском графике, кожумбердынской выборки со срубно-алакульской Южного Приуралья (№ 3, 4). Сверка данных результатов с вычисленными расстояниями Махаланобиса подтвердила прежде всего близость выборок, оказавшихся на графике в центральной области. Внутри этой совокупности базовой является выборка срубной культуры Самаро-Сокского бассейна, продемонстрировавшей минимальные расстояния, во-первых, с покровской и срубной сериями лесостепей Поволжья (№ 9-7 // 0,1; № 9-8 // 0,3; № 7-8 // $0,1)$. Все они происходят из одной большой природной зоны, в частности лесостепного
Волго-Уралья. Во-вторых, самаро-сокская группа близка с алакульскими выборками: петровскими (№ 9-1 // 0,0; № 9-2 // 0,2), кожумбердынского типа (№ 9-3 // 0,2). Дополнительно, рассматривая расстояния именно алакульских выборок, отмечается близость кожумбердынской группы с петровскими $(0,3 ; 0,3)$. Синкретичная срубно-алакульская Южного Приуралья несколько отдалена от них, хотя и не значительно.

Интерпретация полученных результатов и основные выводы. Составленные выборки, относящиеся к алакульской (кожумбердынская группа) культуре и синкретичным срубно-алакульским (южноуральская и зауральская группы) памятникам, неоднородны, состоят в основном из европеоидных краниологических вариантов, умеренно широколицых, с одной стороны, и сравнительно гипоморфных, или мезоморфных, - с другой. Такие же варианты фиксировались в сериях срубной культуры Волго-Уралья [33; 38; и др.]. Эти морфологические комплексы своим происхождением связаны в первую очередь с предшествовавшими хронологически группами населения степей и лесостепей Восточной Европы, с носителями вариантов широко известного в палеоантропологии палеоевропеоидного краниологического типа и в большей степени мезоморфного, долихокранного, клиногнатного, близкого южным европеоидам. Именно последние во многом обусловили суммарные характеристики краниологических серий Восточной Европы в периоды финала средней и поздней бронзы. Это не должно восприниматься как превалирование средиземноморских форм. Показано, что долихокранные, сравнительно узколицые и клиногнатные европеоиды появились на территориях Средней и Северной Европы как минимум с эпохи энеолита и с тех пор развивались в определенной степени самостоятельно, испытывая, разумеется, эпизодические инвазии со стороны ближневосточных и кавказских популяций. При этом усиливалось морфологическое разнообразие в первую очередь южных восточноевропейских групп, появлялись разные модификации в составе исторически, видимо, и таксономически единого южноевропеоидного долихокранного, мезоморфного краниологического типа. Наиболее определенно проявление 
условно средиземноморского комплекса в составе алакульского населения прослеживается по материалам могильника Восточно-Курайлинский I петровского времени [33, с. 125].

Непосредственными хронологическими и, вероятно, генетическими предшественниками ранних групп срубной (покровский этап) и алакульской (петровский этап) культур являлись племена потапово-синташтинского круга, связываемые с Волго-Уральским очагом культурогенеза начала позднебронзового века [10]. Эти группы населения были показательно гетерогенны как на внутригрупповом, так и на межгрупповом уровне, а также по половому составу $[19 ; 29 ; 31 ; 34 ; 35$; и др.], что отразилось и на их прямых потомках, но с тенденцией сглаживания различий. В настоящей работе некоторые различия можно видеть по результатам канонического анализа (рис. 1, 2), где мужские серии покровского этапа продемонстрировали разные морфологические тенденции, а в отношении половой дифференциации это относится к выборкам петровской культуры.

Прослеживаемые на графиках более широкие расстояния между мужскими краниологическими выборками поздней бронзы говорят и об их большей морфологической изменчивости в целом по сравнению с женскими группами. Особенно плотной является центральная часть (рис. 2), где сосредоточены женские выборки лесостепных срубных культур Волго-Уралья и одновременно групп с алакульскими традициями. Тесная морфологическая близость между многими из них устанавливается и по вычисленным расстояниям Махаланобиса. Это говорит о сравнительно гомогенном женском субстрате в ареале лесостепного Волго-Уралья и Западного Казахстана, на базе которого, видимо, формировались физические особенности местных популяций позднебронзового века, в том числе мужской части населения.

Краниологические выборки алакульской группы в сумме морфологически оказались несколько более разнообразны по сравнению со срубными. Их западные коллективы продолжали контакты с восточными группами срубной культуры, что выразилось в погребальном обряде и инвентаре синкретичных срубно-алакульских памятников и подтверж- дается особенностями полученных из них антропологических материалов. Выборки черепов срубной культуры, в частности лесостепной части Волго-Уралья, во многом оказались морфологически тождественны западным алакульским, что выявляется по материалам кожумбердынской группы, представляющей классический алакуль. Это было обусловлено историческими связями представителей двух граничивших между собой культур позднебронзового века, вышедших, вероятно, из единого очага южноуральского культурогенеза, отношения между которыми не пресекались и, видимо, периодически усиливались в период поиска и эксплуатации рудных источников.

Происхождение сравнительно гипоморфного европеоидного антропологического компонента в составе алакульских групп, которое вызывало в конце XX в. дискуссии, следует связывать, по нашим представлениям, именно с волго-уральскими популяциями, но не нижневолжскими: в первую очередь с выходцами из синташтинских, покровских и петровских групп начала поздней бронзы, а во вторую - с влиянием на их фенофонд мезоморфных долихокранных европеоидов из среды носителей сложившейся срубной культуры развитого этапа этой эпохи. Участие в сложении антропологического пласта каких-либо коллективов среднеазиатского происхождения не отрицается, но если это было, то, скорее всего, носило второстепенный характер вследствие инкорпорирования отдельных представителей чужеродного населения.

Восточная группа алакульской культуры продемонстрировала морфологическое сближение с андроновскими / федоровскими выборками, что является показателем другого, именно восточного, направления контактов. Это нормальное явление, демонстрирующее, что не все алакульские группы были морфологически резко отличны от соседних степных популяций федоровского культурного типа. В этой же связи следует учесть краниологические показатели черепов могильника Омского Прииртышья Ермак 4, интерпретируемого как алакульский [7, с. 134], которые близки черепам именно федоровской группы степей Казахстана.

В составе суммарной алакульской краниологической серии встречаются отдельные 


\section{МОРФОЛОГИЯ ДРЕВНИХ ПОПУЛЯЦИЙ}

черепа с уралоидными признаками или теми, которые можно было бы связать с пережиточными специфическими комплексами эпох энеолита - ранней бронзы Казахстана [33; 34; 37]. Если такие черты не являются показателем нормальной внутрипопуляционной изменчивости, то их наличие можно было бы объяснить проявлением линии, пусть даже и опосредованно, более глубоких хронологических связей с потаповско-синташтинским населением, где также вполне определенно был представлен уралоидный компонент, или же эпизодическими синхронными включениями генотипов лесного или сугубо местного происхождения. Следует добавить, что, по предварительным одонтологическим исследованиям, в составе населения упомянутых в настоящей работе культур Волго-Уралья и Западного Казахстана фиксируется наличие двух вариантов. Один имеет высокий процент коленчатой складки метаконида, сочетающийся с отсутствием дистального гребня тригонида, что характерно для северного грацильного типа с восточным уклоном, и может быть интерпретирован в целом как уралоидный. Второй вариант имеет меньшие значения восточных признаков и небольшой процент дистального гребня тригонида - признаки южного грацильного типа [19].

На основе полученных материалов нельзя убедительно говорить о конкретных механизмах биологического взаимодействия коллективов со срубными и алакульскими культурными традициями. Тем не менее очевидно, что продвижение первых на восток не носило характер проникновения в Зауралье именно мужских отрядов и включения в состав нарождающихся групп местной доли женского генофонда, как это прослеживалось по материалам потапово-синташтинского времени Южного Приуралья. По всей видимости, это было постепенное и эпизодическое распространение волго-уральских отрядов на территориях Западного Казахстана, включение в сферу сопутствующих контактов представителей обоих полов, с элементами взаимной ассимиляции носителей этих двух культурных образований.

\section{ПРИМЕЧАНИЯ}

${ }^{1}$ Статья публикуется при поддержке гранта РНФ, проект № 18-18-00137 «Контакты и взаимосвязи населения Урало-Поволжских и Казахстанских степей в период поздней бронзы и раннего железа».

The article is published with the support of a grant from the Russian Science Foundation, project No. 18-18-00137 "Contacts and relationships of the population of the Ural-Volga and Kazakhstan steppes during the Late Bronze Age and Early Iron Age".

${ }^{2}$ Материалы, относящиеся к алакульской культуре Южного Урала и Западного Казахстана, были сгруппированы при консультации В.В. Ткачева, которому коллектив авторов выражает глубокую благодарность и признательность.

${ }^{3}$ К сожалению, не может быть использована часть упомянутых в литературе черепов ряда алакульских могильников ввиду их сомнительного происхождения или весьма плохой сохранности (Мечет-Сай, Киргильда, Кунакбай-Сай, Турсумбай, Селивановский II и др.).

${ }^{4}$ Суммарные данные по последней группе были опубликованы с учетом черепов обоего пола [26]. Данная группа, на основе опубликованных в этой же работе индивидуальных измерений, была разделена на мужскую и женскую выборки и пересчитана согласно половой принадлежности.

${ }^{5}$ Пример расшифровки обозначения: (№ 3-8 // 0,1), где (3-8) - номера выборок; 0,1 - расстояние Махаланобиса. 
ПРИЛОЖЕНИЕ

Таблийа 1. Краниологические и средние статистические показатели мужских черепов алакульской культуры кожумбердынского типа

Table 1. Craniological and average statistical indicators of male skulls of the Alakul culture of the Kozhumberdyn type

\begin{tabular}{|c|c|c|c|c|c|c|c|c|}
\hline \multirow[t]{2}{*}{ Признак } & \multicolumn{3}{|c|}{ Аралча II } & \multirow{2}{*}{\begin{tabular}{|c|}
$\begin{array}{c}\text { Ушкаттинс- } \\
\text { кий I }\end{array}$ \\
$2 / 3$ \\
\end{tabular}} & \multirow{2}{*}{$\begin{array}{c}\begin{array}{c}\text { Елено- } \\
\text { вский }\end{array} \\
2 / 3\end{array}$} & \multirow{2}{*}{$\begin{array}{c}\text { Казачья } \\
\text { Губерля } \\
\text { к. } 6\end{array}$} & \multirow{2}{*}{$\frac{1 *}{\bar{A} / n}$} & \multirow{2}{*}{$\frac{2 * *}{\bar{A} / n}$} \\
\hline & $9 / 3$ & $11 / 2$ & $7 / 6$ & & & & & \\
\hline 1. Продольный диаметр & 197,0 & $200,0 ? ?$ & 203,0 & 196,0 & 190,0 & 191,0 & $195,4 / 5$ & $190,3 / 15$ \\
\hline 8. Поперечный диаметр & 138,0 & $147,5 ? ?$ & 138,0 & 140,0 & 146,0 & 138,0 & $140,0 / 5$ & $138,7 / 15$ \\
\hline 8/1. Черепной указатель & 70,1 & - & 68,0 & 71,4 & 76,8 & 72,3 & $71,7 / 5$ & 73,0 \\
\hline 17. Высотный диаметр & 150,0 & - & - & - & - & 141,0 & $145,5 / 2$ & $142,7 / 6$ \\
\hline 20. Ушная высота & 133,5 & 124,0 & - & 120,0 & 125,0 & 119,0 & $124,3 / 5$ & $121,5 / 12$ \\
\hline 9. Наименьшая ширина лба & 102,0 & - & 95,0 & 100,0 & 105,0 & 97,0 & $99,8 / 5$ & $97,1 / 14$ \\
\hline 11. Ширина основания черепа & 126,0 & - & - & $127,0 ? ?$ & 134,0 & 126,0 & $128,7 / 3$ & $125,4 / 10$ \\
\hline 45. Скуловой диаметр & $138,0 ? ?$ & - & - & - & 137,0 & $138,0 ? ?$ & $137,0 / 1$ & $133,3 / 9$ \\
\hline 48. Верхняя высота лица & 70,0 & - & - & - & 72,0 & 67,5 & $69,8 / 3$ & $69,3 / 12$ \\
\hline 51. Ширина орбиты & 42,5 & - & 42,1 & - & 42,8 & 46,2 & $43,4 / 4$ & $42,3 / 10$ \\
\hline 52. Высота орбиты & 33,3 & - & 30,7 & - & 31,0 & 28,5 & $30,9 / 4$ & $31,7 / 12$ \\
\hline 54. Ширина носа & 22,4 & - & - & - & 28,0 & 25,5 & $25,3 / 3$ & $25,1 / 10$ \\
\hline 55. Высота носа & 51,3 & - & - & - & 52,5 & 50,0 & $51,3 / 3$ & $50,1 / 12$ \\
\hline sc. Симотическая ширина & 9,6 & - & 11,0 & - & 7,9 & 7,4 & $9,0 / 4$ & $9,3 / 9$ \\
\hline ss. Симотическая высота & 4,8 & - & 6,2 & - & 5,3 & 4,5 & $5,2 / 4$ & $5,2 / 9$ \\
\hline FC. Глубина клыковой ямки & 5,9 & - & - & - & 5,7 & 7,3 & $6,3 / 3$ & $5,5 / 8$ \\
\hline 32. Угол наклона лба & - & - & - & - & $86,0^{\circ}$ & $88,0^{\circ}$ & $87,0^{\circ} / 2$ & $82,6^{\circ} / 7$ \\
\hline 72. Угол общелицевой & - & - & - & - & $83,0^{\circ}$ & $81,0^{\circ}$ & $82,0^{\circ} / 2$ & $83,7^{\circ} / 7$ \\
\hline 74. Угол альвеолярной части & - & - & - & - & $75,0^{\circ}$ & $70,0^{\circ}$ & $72,5^{\circ} / 2$ & $73,0 \%$ \\
\hline 75(1). Угол выступания носа & - & - & - & - & 34,0 & $25,0^{\circ} ?$ & $34,0^{\circ} / 1$ & $33,3 \%$ \\
\hline 77. Угол назомалярный & 141,0 & - & $132,0 ?$ & 134,0 & 136,0 & $139,0^{\circ}$ & $137,5 \%$ & $135,4^{\circ} / 12$ \\
\hline Zm. Угол зигомаксиллярный & - & - & - & - & 119,0 & $130,0^{\circ}$ & $124,5^{\circ} / 2$ & $121,3^{\circ} / 8$ \\
\hline Надпереносье & 4,0 & 6,0 & 5,0 & 6,0 & 4,0 & 5,0 & $5,0 / 6$ & $3,9 / 17$ \\
\hline Затылочный бугор & 5,0 & 4,0 & 1,5 & 5,0 & 3,5 & 4,0 & $3,8 / 6$ & $3,8 / 6$ \\
\hline Сосцевидный отросток & 3,0 & 3,0 & 2,0 & 2,5 & 3,0 & 2,5 & $2,7 / 6$ & $2,7 / 12$ \\
\hline
\end{tabular}

Примечание. * - средние показатели новых черепов (мог. Аралча II, Ушкаттинский I, Еленовский, Казачья Губерля); ** - средние показатели кожумбердынской культурной группы с учетом материалов мог. Тасты-бутак 1 и Хабарное. В таблицах 1 и 2 использованы следующие обозначения: «?»-вследствие незначительного разрушения целостности костей, определяющих размер признака, его величина (в определенной степени) условна, но использовать в статистических расчетах можно; «??»- размер признака ориентировочный, следует учитывать, но использовать в статистических расчетах нельзя.

Note. * -average indicators of new skulls (Aralcha II, Ushkattinsky I, Yelenovsky, Kazachya Guberlya burial grounds); ** - average indicators of the Kozhumberdyn cultural group, taking into account materials from Tastybutak 1 and Khabarnoye burial grounds. Tables 1 and 2 provide the following symbols: "?" - due to a slight destruction of the integrity of bones, which determines the size of the sign, its value (to some extent) is conditional, however it can be used in statistical calculations; "??" - the feature size is approximate; it should be taken into account, however it is impossible to use it in statistical calculations. 


\section{МОРФОЛОГИЯ ДРЕВНИХ ПОПУЛЯЦИЙ}

Таблица 2. Краниологические и средние статистические показатели женских черепов алакульской культуры кожумбердынского типа

Table 2. Craniological and average statistical indicators of female skulls of the Alakul culture of the Kozhumberdyn type

\begin{tabular}{|c|c|c|c|c|c|c|c|c|c|c|c|c|c|}
\hline \multirow{2}{*}{ Признак } & \multicolumn{6}{|c|}{ Аралча II } & \multicolumn{4}{|c|}{ Ушкаттинский I } & \multirow{2}{*}{$\begin{array}{c}\begin{array}{c}\text { Еленов- } \\
\text { ский }\end{array} \\
2 / 5\end{array}$} & \multirow{2}{*}{$\begin{array}{l}\text { * } \\
\bar{A} / n\end{array}$} & \multirow{2}{*}{$\begin{array}{l}2^{* *} \\
\bar{A} / n\end{array}$} \\
\hline & $2 / 7$ & $9 / 6$ & $1 / 4$ & $7 / 4$ & $8 / 1 / 1$ & $7 / 7$ & $12 / 2$ & $22 / 1$ & $22 / 4$ & $34 / 1$ & & & \\
\hline $\begin{array}{l}\text { 1. Продольный } \\
\text { диаметр }\end{array}$ & 176,0 & 184,0 & 187,0 & - & 187,0 & 176,0 & - & 180,0 & 191,0 & 177,0 & 184,0 & $\begin{array}{c}182,4 / \\
9\end{array}$ & $\begin{array}{c}179,8 / \\
18\end{array}$ \\
\hline $\begin{array}{l}\text { 8. Поперечный } \\
\text { диаметр }\end{array}$ & 139,0 & $130,0 ? ?$ & - & - & 135,0 & 142,0 & - & 136,0 & 127,0 & - & 137,0 & $\begin{array}{c}136,0 / \\
6\end{array}$ & $\begin{array}{c}133,3 / \\
15\end{array}$ \\
\hline $\begin{array}{l}\text { 8/1. Черепной } \\
\text { указатель }\end{array}$ & 79,0 & - & - & - & 72,2 & 80,7 & - & 75,6 & 66,5 & - & 74,5 & 74,7 & $\begin{array}{c}74,5 / \\
15\end{array}$ \\
\hline $\begin{array}{l}\text { 17. Высотный } \\
\text { диаметр }\end{array}$ & - & - & - & - & - & - & - & - & - & - & - & - & $\begin{array}{c}132,1 / \\
9\end{array}$ \\
\hline $\begin{array}{l}\text { 20. Ушная } \\
\text { высота }\end{array}$ & 117,5 & - & - & & 114,5 & - & - & 115,5 & - & - & - & $\begin{array}{c}115,8 / \\
3\end{array}$ & $\begin{array}{c}116,1 / \\
6\end{array}$ \\
\hline $\begin{array}{l}\text { 9. Наименьшая } \\
\text { ширина лба }\end{array}$ & - & - & - & 91,0 & - & 97,5 & 92,0 & 91,5 & 90,0 & - & 89,5 & $\begin{array}{c}91,9 / \\
6\end{array}$ & $\begin{array}{c}93,2 / \\
15\end{array}$ \\
\hline $\begin{array}{l}\text { 11. Ширина } \\
\text { основания } \\
\text { черепа }\end{array}$ & $125,0 ? ?$ & - & - & - & 123,0 & - & - & 121,0 & - & - & - & $\begin{array}{c}122,0 / \\
2\end{array}$ & $\begin{array}{c}122,0 / \\
5\end{array}$ \\
\hline $\begin{array}{l}\text { 45. Скуловой } \\
\text { диаметр }\end{array}$ & $132,5 ? ?$ & - & $\overline{-}$ & $\overline{-}$ & - & $\overline{-}$ & $\overline{-}$ & - & $\overline{-}$ & - & $125.0 ?$ & $\begin{array}{c}125,0 / \\
1\end{array}$ & $\begin{array}{c}125,8 / \\
12\end{array}$ \\
\hline $\begin{array}{l}\text { 48. Верхняя } \\
\text { высота лица }\end{array}$ & - & - & 74,5 & $49,0 ? ?$ & & & & - & & - & - & $\begin{array}{c}74,5 / \\
1\end{array}$ & $\begin{array}{c}66,3 / \\
12\end{array}$ \\
\hline $\begin{array}{l}\text { 51. Ширина } \\
\text { орбиты }\end{array}$ & 41,0 & - & 44,8 & - & 44,0 & 47,0 & 38,0 & - & 37,3 & 41,0 & - & 41,9 & $\begin{array}{c}41,1 / \\
16\end{array}$ \\
\hline $\begin{array}{l}\text { 52. Высота } \\
\text { орбиты }\end{array}$ & 32,7 & - & 35,6 & - & 29,9 & 30,9 & 34,7 & - & 31,5 & 34,0 & - & 32,8 & $\begin{array}{c}33,4 / \\
18\end{array}$ \\
\hline $\begin{array}{l}\text { 54. Ширина } \\
\text { носа }\end{array}$ & - & - & 22,2 & - & - & - & 22,8 & - & - & - & - & 22,5 & $\begin{array}{c}23,7 / \\
13\end{array}$ \\
\hline $\begin{array}{l}\text { 55. Высота } \\
\text { носа }\end{array}$ & - & - & 53,0 & - & - & - & 53,2 & - & - & - & - & $\begin{array}{c}53,1 / \\
2\end{array}$ & $\begin{array}{c}47,8 / \\
13\end{array}$ \\
\hline $\begin{array}{l}\text { sc. Симотичес- } \\
\text { кая ширина }\end{array}$ & - & - & 5,2 & - & - & 4,7 & 8,0 & - & - & - & - & $\begin{array}{c}6,0 / \\
3\end{array}$ & $\begin{array}{c}8,2 / \\
10\end{array}$ \\
\hline $\begin{array}{l}\text { ss. Симотичес- } \\
\text { кая высота }\end{array}$ & - & - & 3,1 & - & - & 1,3 & 3,4 & - & - & - & - & $\begin{array}{c}2,6 / \\
3\end{array}$ & $\begin{array}{c}3,9 / \\
10\end{array}$ \\
\hline $\begin{array}{l}\text { FC. Глубина } \\
\text { клыковой ямки }\end{array}$ & - & - & - & - & - & - & - & - & - & - & - & - & $5,1 / 9$ \\
\hline $\begin{array}{l}\text { 32. Угол нак- } \\
\text { лона лба }\end{array}$ & - & - & - & - & - & - & - & - & - & - & - & - & $\begin{array}{c}88,0 \% \\
5\end{array}$ \\
\hline $\begin{array}{l}\text { 72. Угол обще- } \\
\text { лицевой }\end{array}$ & - & - & - & - & - & - & - & - & - & - & - & - & $\begin{array}{c}84,6^{\circ} \\
5\end{array}$ \\
\hline $\begin{array}{l}\text { 74. Угол альве- } \\
\text { олярной части }\end{array}$ & - & - & - & - & - & - & - & - & - & - & - & - & $\begin{array}{c}70,8^{\circ} \\
5\end{array}$ \\
\hline $\begin{array}{l}75(1) . \text { Угол } \\
\text { выступания } \\
\text { носа }\end{array}$ & - & - & - & - & - & - & $27,0^{\circ}$ & - & - & - & & $\begin{array}{c}27,0^{\circ} \\
1\end{array}$ & $\begin{array}{c}28,3^{\circ} \\
8\end{array}$ \\
\hline $\begin{array}{l}\text { 77. Угол назо- } \\
\text { малярный }\end{array}$ & - & - & - & $134,0^{\circ}$ & - & $136,0^{\circ}$ & $150,0^{\circ}$ & $142,0^{\circ} ? ?$ & $137,0^{\circ}$ & - & $145,0^{\circ}$ & $\begin{array}{c}140,4 \% \\
5\end{array}$ & $\begin{array}{c}137,3^{\circ} \% \\
12\end{array}$ \\
\hline $\begin{array}{l}\mathrm{Zm.} \mathrm{Угол} \mathrm{зиго-} \\
\text { максиллярный }\end{array}$ & - & - & - & - & - & - & - & - & - & - & - & - & $\begin{array}{c}123,0^{\circ} \% \\
9\end{array}$ \\
\hline Надпереносье & 4,0 & - & 2,5 & 2,5 & 2,5 & 4,0 & 2,5 & 4,0 & 2,5 & 1,5 & 4,0 & $3,0 / 10$ & $2,5 / 19$ \\
\hline $\begin{array}{l}\text { Затылочный } \\
\text { бугор }\end{array}$ & 0,5 & - & 2,0 & 1,0 & 0,5 & - & - & 0,5 & 1,0 & 1,5 & 0,0 & $0,9 / 8$ & $0,9 / 9$ \\
\hline $\begin{array}{l}\text { Сосцевидный } \\
\text { отросток }\end{array}$ & 1,5 & - & 1,0 & 2,0 & 1,0 & - & 1,0 & 1,0 & 1,5 & 1,0 & 2,0 & $1,3 / 9$ & $1,4 / 10$ \\
\hline
\end{tabular}

Примечание. * - средние показатели новых черепов (мог. Аралча II, Ушкаттинский I, Еленовский); ** - средние показатели кожумбердынской культурной группы с учетом материалов мог. Тасты-бутак 1 и Хабарное, Восточно-Курайлинский I (курган 37).

Note. *-average indicators of new skulls (Aralcha II, Ushkattinsky I, Yelenovsky, Kazachya Guberlya burial grounds); ** - average indicators of the Kozhumberdyn cultural group, taking into account materials from Tastybutak 1 and Khabarnoye, Vostochno-Kuraylinskiy I (kurgan 37) burial grounds. 
Таблица 3. Памятники, давшие краниологический материал из погребений с алакульскими культурными традициями Южного Приуралья и Западного Казахстана

Table 3. Monuments that gave craniological material from burials with Alakul cultural traditions of the Southern Urals and Western Kazakhstan

\begin{tabular}{|c|c|c|}
\hline Группа & Памятник & Автор, год публикации \\
\hline \multirow{6}{*}{$\begin{array}{l}\text { Петровская культура } \\
\text { (ранний алакуль) }\end{array}$} & Васильевка III (п. 7) & Хохлов, 1998 [29] \\
\hline & Кривое Озеро - 1/3 & Рыкушина, 2003 [25] \\
\hline & Степное $\langle\mathrm{M} »-5 / 1$ & Китов, 2011 [19] \\
\hline & Солончанка $1 \mathrm{~A}-3 / 1$ & Китов, 2011 [19] \\
\hline & Восточно-Курайлинский I & Хохлов, 1998 [29], Китов, 2011 [19] \\
\hline & Танаберген II & Хохлов, 1998 [29], Китов, 2011 [19] \\
\hline \multirow{4}{*}{$\begin{array}{l}\text { Срубно-алакульская группа } \\
\text { Южного Приуралья }\end{array}$} & Герасимовка I & Акимова, 1968 [1] \\
\hline & Комиссаровский & Бужилова, 2005 [11] \\
\hline & Уранбаш-южный (к. 8) & Хохлов, 2017 [34] \\
\hline & Бариновка I & Хохлов, 2002 [32] \\
\hline \multirow{5}{*}{$\begin{array}{l}\text { Срубно-алакульская группа } \\
\text { Зауралья }\end{array}$} & Александро-Невский I & Китов, 2009 [18] \\
\hline & Каменный Дол & Китов, Хохлов, 2008 [20] \\
\hline & Наровчатовский & Китов, Хохлов, 2008 [20] \\
\hline & Кирса 3 & Китов, Хохлов, 2008 [20] \\
\hline & Лисьи Горы & Китов, Хохлов, 2008 [20] \\
\hline \multirow{7}{*}{$\begin{array}{l}\text { Алакульская культура } \\
\text { (кожумбердынская группа) }\end{array}$} & Хабарное & Алексеев, 1964 [5] \\
\hline & Тасты-бутак 1 & Гинзбург, 1962 [13] \\
\hline & Казачья Губерля (к. 6) & Новые материалы \\
\hline & Ушкаттинский I & Новые материалы \\
\hline & Аралча II & Новые материалы \\
\hline & Еленовский & Новые материалы \\
\hline & Восточно-Курайлинский I (к. 37) & Хохлов, 1998 [29], Китов, 2011 [19] \\
\hline
\end{tabular}

\section{Таблица 4. Нагрузки на канонические векторы}

\section{Table 4. Loads on the canonical vectors}

\begin{tabular}{|c|c|c|c|c|c|c|}
\hline \multirow{2}{*}{ Признак } & \multicolumn{3}{|c|}{ Мужская группа } & \multicolumn{3}{c|}{ Женская группа } \\
\cline { 2 - 7 } & КВ I & КВ II & КВ III & КВ I & КВ II & КВ III \\
\hline 1 & $\mathbf{- 0 . 6 2}$ & 0.29 & -0.38 & $\mathbf{0 , 4 6}$ & 0,15 & 0,11 \\
\hline 8 & $\mathbf{0 . 4 6}$ & -0.45 & -0.26 & $\mathbf{- 0 , 4 1}$ & $-0,26$ & $-0,02$ \\
\hline 17 & -0.11 & -0.19 & $\mathbf{0 . 6 0}$ & 0,37 & 0,03 & 0,03 \\
\hline 9 & -0.20 & 0.20 & $\mathbf{0 . 5 1}$ & 0,21 & 0,05 & 0,03 \\
\hline 45 & -0.08 & -0.37 & $\mathbf{- 0 . 6 4}$ & $-0,35$ & 0,32 & $-0,05$ \\
\hline 48 & -0.06 & 0.09 & 0.10 & $-0,08$ & 0,07 & $\mathbf{- 0 , 7 7}$ \\
\hline 51 & $\mathbf{0 . 6 9}$ & 0.52 & 0.05 & $-0,11$ & $-0,05$ & $\mathbf{0 , 6}$ \\
\hline 52 & -0.08 & -0.01 & 0.14 & 0,27 & 0,44 & $\mathbf{- 0 , 6}$ \\
\hline 54 & 0.36 & 0.10 & 0.41 & $-0,15$ & $-0,24$ & $-0,3$ \\
\hline 55 & 0.04 & 0.26 & -0.22 & 0,13 & $-0,25$ & $\mathbf{1 , 1 8}$ \\
\hline 77 & 0.18 & -0.01 & -0.01 & $-0,19$ & 0,16 & 0,18 \\
\hline Zm & 0.27 & -0.08 & -0.08 & $-0,21$ & $-0,21$ & 0,01 \\
\hline $75(1)$ & 0.02 & $\mathbf{0 . 7 9}$ & -0.20 & $\mathbf{0 , 7 7}$ & $\mathbf{- 0 , 4 7}$ & 0,08 \\
\hline SS:SC & 0.17 & $\mathbf{- 0 . 5 3}$ & -0.04 & $-0,46$ & $\mathbf{0 , 8 8}$ & 0,12 \\
\hline Собственное значение & 9.93 & 7.38 & 5.05 & 7,88 & 3,47 & 2,79 \\
\hline \% изменчивости & 30,0 & 22,0 & 15,0 & 36,55 & 16,08 & 12,92 \\
\hline
\end{tabular}




\section{МОРФОЛОГИЯ ДРЕВНИХ ПОПУЛЯЦИЙ}

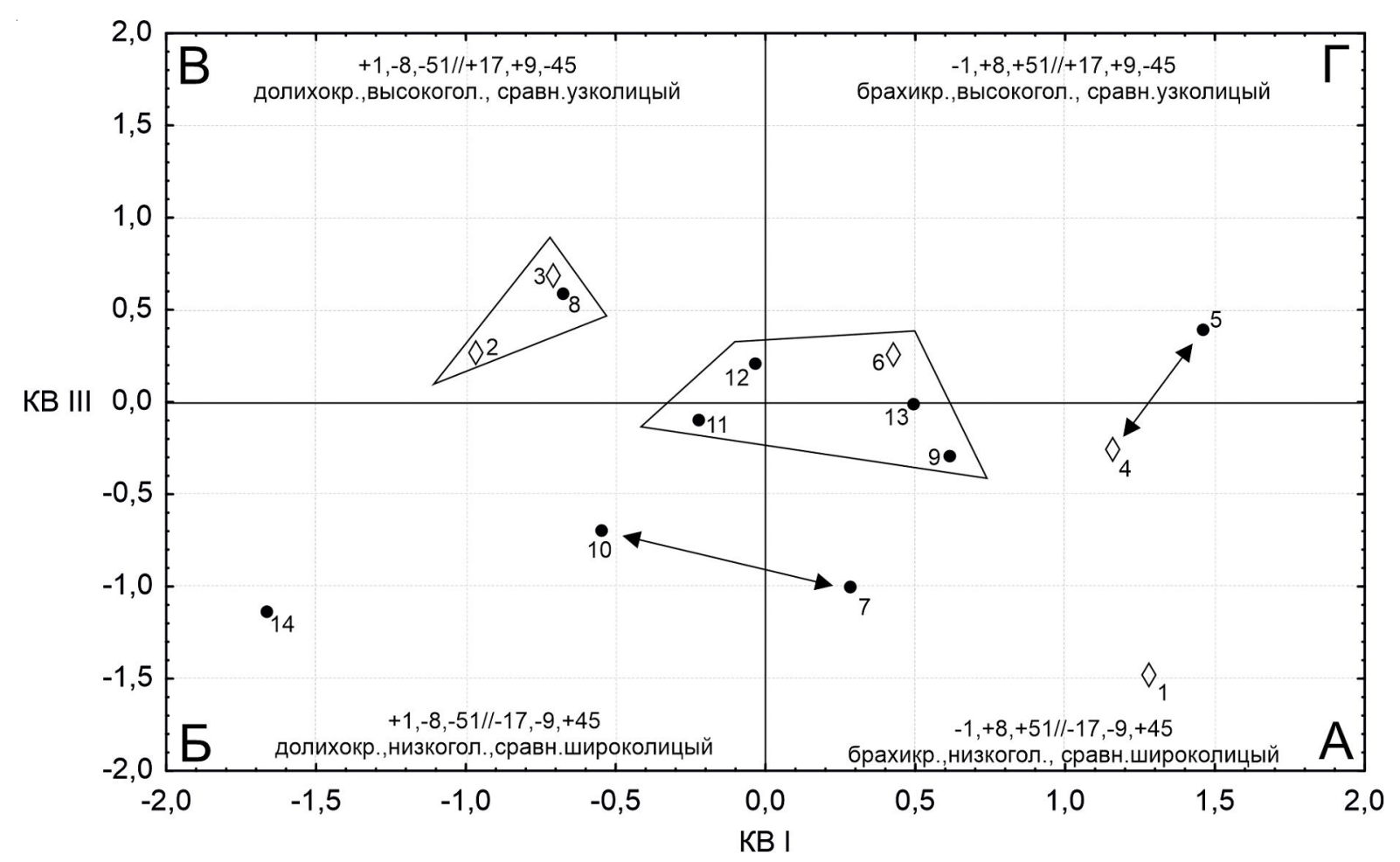

Рис. 1. Распределение мужских краниологических выборок срубной и алакульской культур бронзового века в графическом пространстве КВ I и КВ III:

1 - петровская культура Приуралья; 2 - срубно-алакульская группа памятников Южного Приуралья; 3 - алакульская культура (кожумбердынская группа памятников);

4 - алакульская культура юго-востока Западной Сибири; 5 - андроновская / федоровская культура Казахстана;

6 - срубно-алакульская группа памятников Зауралья; 7 - покровская культура Нижнего Поволжья;

8 - покровская культура Самарского Поволжья; 9 - покровская культура Приуралья;

10 - срубная культура Поволжской степи; 11 - срубная культура Поволжской лесостепи;

12 - срубная культура Самаро-Сокского бассейна; 13 - срубная культура Приуральской лесостепи; 14 - срубная культура Приуральской степи

Fig. 1. Distribution of male craniological series of the Srubnaya and Alakul cultures of the Bronze Age in the graphic space of CV I и CV III:

1 - Petrovka culture of the Cis-Urals; 2 - Srubnaya-Alakul group of sites of the Southern Urals; 3 - Alakul culture (Kozhumberdy group of monuments);

4 - Alakul culture of the South-East of Western Siberia; 5 - Andronovo / Fedorovo culture of Kazakhstan;

6 - Srubnaya-Alakul group of sites of the Trans-Urals; 7 - Pokrovka culture of the Lower Volga region; 8 - Pokrovka culture of the Samara Volga region; 9 - Pokrovka culture of the Urals;

10 - Srubnaya culture of the Volga steppe; 11 - Srubnaya culture of the Volga forest-steppe;

12 - Srubnaya culture of the Samara-Sok basin; 13 - Srubnaya culture of the Ural forest-steppe; 14 - Srubnaya culture of the Ural steppe 
А.А. Хохлов, Е.П. Китов, Ю.О. Капинус. К проблеме антропологических связей

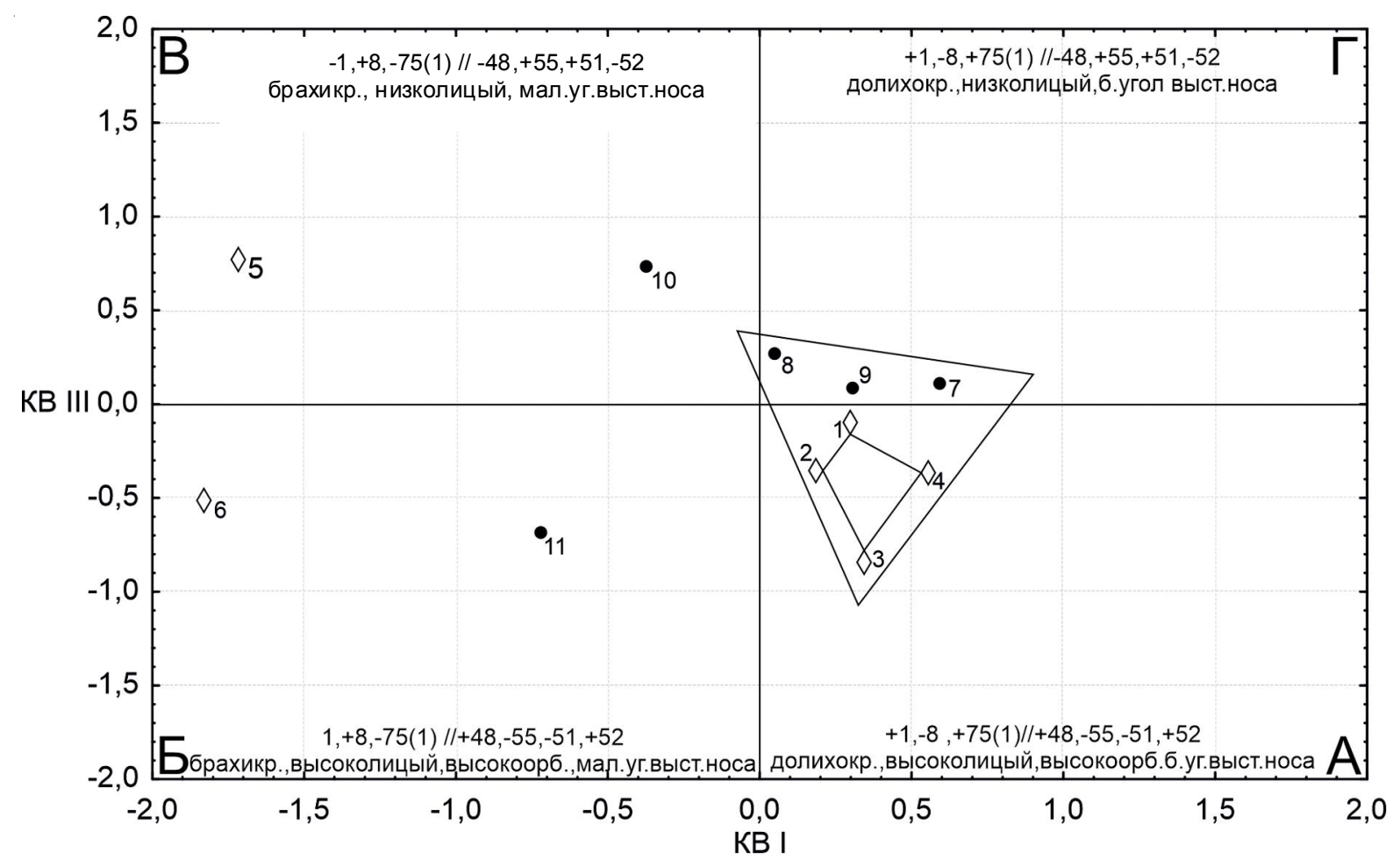

Рис. 2. Распределение женских краниологических выборок срубной и алакульской культур бронзового века в графическом пространстве КВ I и КВ III:

1 - петровская культура Приуралья; 2 - петровская культура Казахстана; 3 - алакульская культура (кожумбердынская группа памятников); 4 - срубно-алакульская группа памятников Южного Приуралья;

5 - алакульская культура юго-востока Западной Сибири; 6 - андроновская / федоровская культура Казахстана;

7 - покровская культура Самарского Поволжья; 8 - срубная культура Поволжской лесостепи;

9 - срубная культура Самаро-Сокского бассейна; 10 - срубная культура Приуральской лесостепи; 11 - срубная культура Приуральской степи

Fig. 2. Distribution of female craniological series of the Srubnaya and Alakul cultures of the Bronze Age in the graphic space of CV I и CV III:

1 - Petrovka culture of the Cis-Urals; 2 - Petrovka culture of Kazakhstan; 3 - Alakul culture (Kozhumberdy group of sites); 4 - Srubnaya-Alakul group of sites of the Southern Urals;

5 - Alakul culture of the South-East of Western Siberia; 6 - Andronovo / Fedorovo culture of Kazakhstan; 7 - Pokrovka culture of the Samara Volga region; 8 - Srubnaya culture of the Volga forest-steppe; 9 - Srubnaya culture of the Samara-Sok basin; 10 - Srubnaya culture of the Ural forest-steppe; 11 - Srubnaya culture of the Ural steppe 


\section{СПИСОК ЛИТЕРАТУРЫ}

1. Акимова, М. С. Материалы к антропологии древнего населения Южного Урала / М. С. Акимова // Археология и этнография Башкирии. Т. 3. Уфа : БФАН СССР, 1968. - С. 391-417.

2. Алаева, И. П. Культурная специфика памятников позднего бронзового века степной зоны Южного Зауралья : автореф. дис. .... канд. ист. наук / Алаева Ирина Павловна. - М., 2015. - 32 с.

3. Алаева, И. П. Факторы территориальной специфики алакульских культур в бронзовом веке Урало-Казахстанского региона / И. П. Алаева // Фундаментальная и прикладная наука. - Челябинск : Челяб. гос. пед. ун-т, 2016. - С. 4-5.

4. Алексеев, В. П. Краниометрия. Методика антропологических исследований / В. П. Алексеев, Г. Ф. Дебец. - М. : Наука, 1964. - 127 с.

5. Алексеев, В. П. Антропологический тип населения западных районов распространения андроновской культуры / В. П. Алексеев // Проблемы этнической антропологии Средней Азии : сб. науч. ст. - Ташкент : Наука, 1964. - С. 20-28.

6. Алексеев, В. П. Антропология андроновской культуры / В. П. Алексеев // Советская археология. - 1967. - Вып. 1. - С. 22-26.

7. Багашёв, А. Н. Палеоантропология Западной Сибири. Лесостепь в эпоху раннего железа / А. Н. Багашёв. - Новосибирск : Наука, 2000. -371 с.

8. Багашёв, А. Н. Антропология Западной Сибири / А. Н. Багашёв. - Новосибирск : Наука, 2017. $408 \mathrm{c}$.

9. Богданов, С. В. Комиссаровский некрополь / С. В. Богданов // Каргалы. В 5 т. Т. 4. Некрополи на Каргалах; население Каргалов: палеоантропологические исследования / под ред. Е. Н. Черныха. - М. : Яз. слав. культуры, 2005. - С. 70-99.

10. Бочкарев, В.С. Культурогенез и развитие металлопроизводства в эпоху поздней бронзы (по материалам южной половины Восточной Европы) / В.С. Бочкарев // Древние индоиранские культуры Волго-Уралья (II тыс. до н.э.). - Самара : Изд-во СамГПУ, 1995. - С.114-123.

11. Бужилова, А. П. Население Каргалов: палеоантропологические исследования / А. П. Бужилова // Каргалы. В 5 т. Т. 4. Некрополи на Каргалах; население Каргалов: палеоантропологические исследования / под ред. Е. Н. Черныха. - М. : Яз. слав. культуры, 2005. - С. 126-150.

12. Васильев, И. Б. Потаповский курганный могильник индоиранских племен на Волге / И. Б. Васильев, П. Ф. Кузнецов, А. П. Семёнова. - Самара : Самар. ун-т, 1994. - 207 с.

13. Гинзбург, В. В. Материалы к антропологии населения Западного Казахстана в эпоху бронзы : (Захоронения могильника Тасты-Бутак 1 в Актюбин- ской области) : [приложение] / В. В. Гинзбург // Сорокин, В. С. Могильник бронзовой эпохи Тасты-Бутак 1 в Западном Казахстане / В. С. Сорокин. - М. ; Л. : АН СССР, 1962. - С. 186-198.

14. Гинзбург, В. В. Палеоантропология Средней Азии / В. В. Гинзбург, Т. А. Трофимова. - М. : Наука, 1972. - 371 с.

15. Гончаров, И. А. Программа MultiCan для анализа многомерных массивов данных с использованием статистик выборок и параметров генеральной совокупности (MultiCan) / И. А. Гончаров, Н. Н. Гончарова. - М., 2016. - Свидетельство о регистрации прав на ПО № 2016610803.

16. Дрёмов, В. А. Население Верхнего Приобья в эпоху бронзы (антропологический очерк) / В. А. Дрёмов. - Томск : Изд-во Том. ун-та, 1997. - 260 с.

17. Китов, Е. П. Предварительное сообщение по новым краниологическим материалам из могильников срубной культуры Южного Урала / Е. П. Китов // XVII Уральское археологическое совещание. - Екатеринбург; Сургуг : Магеллан, 2007. - С. 143-144.

18. Китов, Е. П. Палеоантропологические данные могильника Александро-Невский I: к вопросу о происхождении населения срубно-алакульского времени Южного Зауралья / Е. П. Китов // Magistra Vitae : электрон. журн. по ист. наукам и археологии. - 2009. - № 38 (176). - С. 5-9.

19. Китов, Е. П. Палеоантропология населения Южного Урала эпохи бронзы : автореф. дис. ... канд. ист. наук / Китов Егор Петрович. - М., 2011. - 26 с.

20. Китов, Е. П. Палеоантропология срубноалакульского времени Южного Урала / Е. П. Китов, А.А. Хохлов // Вестник антропологии. - 2008. № 16. - С. 71-83.

21. Козинцев, А. Г. Происхождение андроновцев (по краниологическим данным) / А. Г. Козинцев // Человек: его биологическая и социальная история. В 2 т. Т. 1 : тр. Междунар. конф. (г. Москва, 9-12 нояб. 2009 г.). - М. : Одинц. гуманитар. ун-т, 2010. - C. 119-123.

22. Купцова, Л. В. Срубная культура Оренбургского Предуралья (по материалам погребальных памятников) : автореф. дис. ... канд. ист. наук / Купцова Лидия Владимировна. - СПб., 2016. - 21 с.

23. Лопатин, В. А. Смеловский могильник: модель локального культурогенеза в степном Заволжье (середина II тыс. до н. э.) / В. А. Лопатин. Саратов : Наука, 2010. - 242 с.

24. Моргунова, Н. Л. Могильник Уранбаш-южный / Н. Л. Моргунова // Каргалы. В 5 т. Т. 4. Некрополи на Каргалах; население Каргалов: палеоантропологические исследования / под ред. Е. Н. Черныха. -М. : Яз. слав. культуры, 2005. - С. 100-124.

25. Рыкушина, Г. В. Антропологическая характеристика населения эпохи бронзы Южного Урала по материалам могильника Кривое Озеро : [приложе- 
ние] / Г. В. Рыкушина // Виноградов, Н. Б. Могильник бронзового века Кривое Озеро в Южном Зауралье / Н. Б. Виноградов. - Челябинск : Юж.-Урал. кн. изд-во, 2003.-С. 345-360.

26. Солодовников, К. Н. Краниологические материалы эпохи бронзы Казахстана / К. Н. Солодовников, М. П. Рыкун, В. Г. Ломан // Вестник археологии, антропологии и этнографии. - 2013. - № 3 (22). C. 113-131.

27. Ткачев, В. В. Уральско-Мугоджарский горно-металлургический центр эпохи поздней бронзы / В. В. Ткачев // Российская археология. - 2011. Вып. 2. - С. 43-55.

28. Ткачев, В. В. Горно-металлургическое производство в структуре хозяйственно-культурных моделей западной периферии алакульской культуры / В. В. Ткачев // Уральский исторический вестник. -2019. - № 1 (62). - С. 38-47. - DOI: 10.30759/ 1728-9718-2019-1(62)-38-47.

29. Хохлов, А. А. Палеоантропология пограничья лесостепи и степи Волго-Уралья в эпохи неолита - бронзы : автореф. дис. ... канд. ист. наук / Хохлов Александр Александрович. - М., 1998. - 23 с.

30. Хохлов, А. А. Краниологические материалы срубной культуры юга Среднего Поволжья / А. А. ХоХлов // Народы России: от прошлого к настоящему. В 2 ч. Ч. 2. Антропология : сб. науч. ст. - М. : Старый Сад, 2000.- C. 217-242.

31. Хохлов, А. А. Палеоантропология эпохи бронзы Самарского Поволжья / А. А. Хохлов // Известия Самарского научного центра РАН. Спец. вып. «История Самарского Поволжья с древнейших времен до наших дней. Бронзовый век». - 2000. - С. 309-332.

32. Хохлов, А. А. Палеоантропология могильника срубной культуры Бариновка I / А. А. Хохлов // Вопросы археологии Поволжья : сб. науч. ст. Самара : СамГПУ, 2002. - Вып. 2. - С. 134-144.

33. Хохлов, А. А. Морфогенетические процессы в Волго-Уралье в эпоху раннего голоцена (по краниологическим материалам мезолита - бронзового века) / А. А. Хохлов. - Самара : СГСПУ, 2017. $-368 \mathrm{c}$.

34. Хохлов, А. А. Специфика антропологического состава носителей потапово-синташтинских культурных традиций (по краниологическим материалам Поволжья и Урала переходного времени от средней к поздней бронзе) / А. А. Хохлов, Е. П. Китов // Процесс культурогенеза начальной поры позднего бронзового века Волго-Уральского региона (вопросы хронологии, периодизации, историографии) : материалы Междунар. науч. конф. (12-14 мая 2014 г.). - Самара : Изд-во ПГСГА, 2014. -С. 131-142.

35. Хохлов, А. А. Теоретические и практические аспекты проблемы происхождения физического облика носителей культур синташтинского круга позднего этапа эпохи бронзы / А. А. Хохлов,
Е. П. Китов // Поволжская археология. - 2019. № 1 (27). - С. 59-71.

36. Черных, Е. Н. Каргалы. Забытый мир / Е. Н. Черных. - M. : Nox, 1997. - 177 с.

37. Чикишева, Т. А. Динамика антропологической дифференциации населения юга Западной Сибири в эпохи неолита - раннего железа / Т. А. Чикишева. - Новосибирск : ИАЭТ СО РАН, 2012. - 468 с.

38. Шевченко, А. В. Палеоантропологические данные к вопросу о происхождении населения срубной культурно-исторической общности / А. В. Шевченко // Проблемы антропологии древнего и современного населения севера Евразии : сб. науч. ст. - Л. : Наука, 1984. - С. 55-73.

39. Шевченко, А. В. Палеоантропология срубников Поволжья в сравнительно-антропологическом освещении / А. В. Шевченко // Археология России. Свод археологических источников. Т. 1. Памятники срубной культуры. Волго-Уральское междуречье. - Саратов : Изд-во Сарат. гос. ун-та, 1993.C. $101-105$.

40. Юсупов, Р. М. Антропология населения срубной культуры Южного Приуралья / Р. М. Юсупов // Материалы по эпохе бронзы и раннего железа Южного Приуралья и Нижнего Поволжья : сб. науч. ст. - Уфа : БНЦ УрО АН СССР, 1989. - С. 127-138.

41. A Bronze Age Landscape in the Russian Steppes. The Samara Valley Project / D. W. Anthony, D. R. Brown, A. A. Khokhlov [et al.]. - Los Angeles : UCLA Cotsen Institute of Archaeology Press, 2016. 513 p.-DOI: 10.1017/aaq.2017.23.

42. Population Genomics of Bronse Age Eurasia / M. E. Allentoft [et al.] // Nature. - 2015. - Vol. 522.P. 167-172.-DOI: 10.1038/nature14507.

43. The Formation of Human Populations in South and Central Asia / V. Narasimhan [et al.] // Science. 2019. - Vol. 365, iss. 6457, eaat7487. - DOI:10.1126/ science.aat 7487 .

\section{REFERENCES}

1. Akimova M.S. Materialy k antropologii drevnego naseleniya Yuzhnogo Urala [Materials for Anthropology of the Ancient Population of the South Urals]. Arkheologiya i etnografiya Bashkirii. T. 3 [Archaeology and Ethnography of Bashkiria. Vol. III]. Ufa, BFAN SSSR, 1968, pp. 126-150.

2. Alaeva I.P. Kulturnaya spetsifika pamyatnikov pozdnego bronzovogo veka stepnoy zony Yuzhnogo Zauralya: avtoref. dis. ... kand. ist. nauk [Cultural Specifics of the Late Bronze Age Sites from the Steppe Zone of the South Trans-Urals. Cand. hist. sci. abs. diss.]. Moscow, 2015. 32 p.

3. Alaeva I.P. Faktory territorialnoy spetsifiki alakulskikh kultur v bronzovom veke Uralo- 
Kazakhstanskogo regiona [Factors of the Territorial Specificity of Alakul Cultures in the Bronze Age of the Ural-Kazakhstan Region]. Fundamentalnaya $i$ prikladnaya nauka [Basic and Applied Science]. Chelyabinsk, Chelyabinskiy gosudarstvennyy pedagogicheskiy universitet, 2016, pp. 4-5.

4. Alekseev V.P., Debets G.F. Kraniometriya. Metodika antropologicheskikh issledovaniy [Craniometry. Methodology of Anthropological Research]. Moscow, Nauka Publ., 1964, 127 p.

5. Alekseev, V.P. Antropologicheskiy tip naseleniya zapadnykh rayonov rasprostraneniya andronovskoy kultury [Anthropological Type of Population in the Western Regions of the Spread of Andronovo Culture]. Problemy etnicheskoy antropologii Sredney Azii: sb. nauch. st. [Problems of Ethnic Anthropology of Central Asia. Collection of Scientific Articles]. Tashkent, Nauka Publ., 1964, pp. 20-28.

6. Alekseev V.P. Antropologiya andronovskoy kultury [Anthropology of Andronovo Culture]. Sovetskaya arkheologiya [Soviet Archaeology], 1967, iss. 1, pp. 22-26.

7. Bagashev A.N. Paleoantropologiya Zapadnoy Sibiri. Lesostep v epokhu rannego zheleza [Paleoanthropology of Western Siberia. Forest-Steppe in the Era of Early Iron]. Novosibirsk, Nauka Publ., 2000.371 p.

8. Bagashev A.N. Antropologiya Zapadnoy Sibiri [Anthropology of Western Siberia]. Novosibirsk, Nauka Publ., 2017. 408 p.

9. Bogdanov S.V. Komissarovskiy nekropol [Cemetery of Komissarovsky]. Kargaly. $V 5$ t. T. 4. Nekropoli na Kargalakh; naselenie Kargalov: paleoantropologicheskie issledovaniya [Kargaly. In 5 Vols. Vol. 4. Cemeteries on the Kargaly. Population of Kargaly: Paleoanthropological Studies]. Moscow, Yazyki slavyanskoy kultury Publ., 2005, pp.70-99.

10. Bochkarev V.S. Kulturogenez i razvitie metalloproizvodstva $\mathrm{v}$ epokhu pozdney bronzy (po materialam yuzhnoy poloviny Vostochnoy Evropy) [Cultural Genesis and Development of Metal Production in the Late Bronze Age (Based on the Materials of the Southern Half of Eastern Europe)]. Drevnie indoiranskie kultury Volgo-Uralya (II tys. do n.e.) [Ancient Indo-Iranian Cultures of the VolgaUrals (II Millennium BC)]. Samara, Izd-vo SamGPU, 1995, pp.114-123.

11. Buzhilova A.P. Naseleniye Kargalov: paleoantropologicheskie issledovaniya [Kargaly Population: Paleoanthropological Studies]. Kargaly. $V$ t. T. 4. Nekropoli na Kargalakh; naselenie Kargalov: paleoantropologicheskie issledovaniya [Kargaly. In 5 Vols. Vol. 4. Cemeteries on the Kargaly. Population of Kargaly: Paleoanthropological Studies]. Moscow, Yazyki slavyanskoykultury Publ., 2005, pp. 126-150.
12. Vasilyev I.B., Kuznetsov P.F., Semenova A.P. Potapovskiy kurgannyy mogilnik indoiranskikh plemen na Volge [Potapovsky Cemetery of IndoIranian Tribes on the Volga River]. Samara, Samarskiy universitet, 1994. $207 \mathrm{p}$.

13. Ginzburg V.V. Materialy k antropologii naseleniya Zapadnogo Kazakhstana v epokhu bronzy: (Zakhoroneniya mogilnika Tasty-Butak $1 \mathrm{v}$ Aktyubinskoy oblasti): [prilozhenie] [Materials on the Anthropology of the Population of Western Kazakhstan in the Bronze Age. (Burials of the Cemetery Tasty-Butak 1 in the Aktobe Region)]. Sorokin V.S. Mogilnik bronzovoy epokhi Tasty-Butak $1 v$ Zapadnom Kazakhstane [The Cemetery of the Bronze Age Tasty-Butak I in Western Kazakhstan]. Moscow, Leningrad, AN SSSR, 1962, pp. 186-198.

14. Ginzburg V.V., Trofimova T.A. Paleoantropologiya Sredney Azii [Paleoanthropology of Central Asia]. Moscow, Nauka Publ., 1972. 371 p.

15. Goncharov I.A., Goncharova N.N. Programma MultiCan dlya analiza mnogomernykh massivov dannykh s ispolzovaniem statistik vyborok $i$ parametrov generalnoy sovokupnosti (MultiCan) [MultiCan Program for the Analysis of Multidimensional Data Arrays Using Statistics of Samples and Parameters of the General Population (MultiCan)]. Moscow, 2016. Certificate of registration of rights to software no. 2016610803.

16. Dremov V.A. Naselenie Verkhnego Priobya v epokhu bronzy (antropologicheskiy ocherk) [The Population of the Upper $\mathrm{Ob}$ in the Bronze Age (Anthropological Essay)]. Tomsk, Izd-vo Tomskogo universiteta, 1997. 260 p.

17. Kitov E.P. Predvaritelnoe soobshchenie po novym kraniologicheskim materialam iz mogilnikov srubnoy kultury Yuzhnogo Urala [Preliminary Report on New Craniological Materials from the Burial Sites of the Srubnaya Culture of the Southern Urals]. XVII Uralskoe arkheologicheskoe soveshchanie $\left[17^{\text {th }}\right.$ Ural Archaeological Conference]. Yekaterinburg, Surgut, Magellan Publ., 2007, pp. 143-144.

18. Kitov E.P. Paleoantropologicheskie dannye mogilnika Aleksandro-Nevskiy I: k voprosu o proiskhozhdenii naseleniya srubno-alakulskogo vremeni Yuzhnogo Zauralya [Paleoanthropological Data of the Burial Ground Alexander Nevsky I: On the Issue of the Origin of the Srub-Alakul Population of the Southern Trans-Urals]. Magistra Vitae: elektron. zhurn. po ist. naukam i arkheologii [Magistra Vitae: An Electronic Journal of Historical Sciences and Archeology], 2009, no. 38 (176), pp. 5-9.

19. Kitov E.P. Paleoantropologiya naseleniya Yuzhnogo Urala epokhi bronzy: avtoref. dis. ... kand. ist. nauk [Paleoanthropology of the Population of the Southern Urals of the Bronze Age. Cand. hist. sci. abs. diss.]. Moscow, 2011. 26 p. 
20. Kitov E.P. Paleoantropologiya srubnoalakulskogo vremeni Yuzhnogo Urala [Paleoanthropology of the Srubno-Alakul Time of the Southern Urals]. Vestnik antropologii [Bulletin of Anthropology], 2008, no. 16, pp. 71-83.

21. Kozintsev A.G. Proiskhozhdenie andronovtsev (po kraniologicheskim dannym) [Origin of Andronovites (According to Craniological Data)]. Chelovek: ego biologicheskaya $i$ sotsialnaya istoriya. V 2 t. T. 1: tr. Mezhdunar. konf. (g. Moskva, 9-12 noyab. 2009 g.) [Man: His Biological and Social History. In 2 Vols. Vol. 1. Proceedings of the International Conference (Moscow, November 9-12, 2009]. Moscow, Odintsovskiy gumanitarnyy universitet, 2010, pp. 119-123.

22. Kuptsova L.V. Srubnaya kultura Orenburgskogo Preduralya (po materialam pogrebalnykh pamyatnikov): avtoref. dis. ... kand. ist. nauk [Srubnaya Culture of the Orenburg Cis-Urals (Based on Materials from Funerary Monuments). Cand. hist. sci. abs. diss.]. Saint Petersburg, 2016. 21 p.

23. Lopatin V.A. Smelovskiy mogilnik: model lokalnogo kulturogeneza v stepnom Zavolzhye (seredina II tys. do n. e.) [Smelovsky Burial Ground: A Model of Local Cultural Genesis in the Steppes of the Volga Region (Mid. $2^{\text {nd }}$ Millennium BC)]. Saratov, Nauka Publ., 2010. 242 p.

24. Morgunova N.L. Mogilnik Uranbashyuzhnyy [Uranbash-South Burial Ground]. Kargaly. V 5 t. T. 4. Nekropoli na Kargalakh; naselenie Kargalov: paleoantropologicheskie issledovaniya [Kargaly. Necropolises in the Kargaly; Kargaly Population: Paleoanthropological Studies]. Moscow, Yazyki slavyanskoy kultury Publ., 2005, pp. 100-124.

25. Rykushina G.V. Antropologicheskaya kharakteristika naseleniya epokhi bronzy Yuzhnogo Urala po materialam mogilnika Krivoe Ozero: [prilozhenie] [Anthropological Characteristics of Population of the Bronze Age from Southern Urals (Based on the Materials of the Burial Ground Krivoe Ozero)]. Vinogradov N.B. Mogilnik bronzovogo veka Krivoe Ozero v Yuzhnom Zauralye [Burial Site of the Bronze Age Krivoe Ozero in the South Trans-Urals]. Chelyabinsk, Yuzhno-Uralskoe knizhnoe izdatelstvo, 2003, pp. 345-360.

26. Solodovnikov K.N., Rykun M.P., Loman V.G. Kraniologicheskie materialy epokhi bronzy Kazakhstana [Craniological Materials of the Bronze Age of Kazakhstan]. Vestnik arkheologii, antropologii $i$ etnografii [Bulletin of Archaeology, Anthropology and Ethnography], 2013, no. 3 (22), pp. 113-131.

27. Tkachev V.V. Uralsko-Mugodzharskiy gornometallurgicheskiy tsentr epokhi pozdney bronzy [UralMugodzharsky Mining and Metallurgical Center of the Late Bronze Age]. Rossiyskaya Arkheologiya [Russian Archaeology], 2011, iss. 2, pp. 43-55.
28. Tkachev V.V. Gorno-metallurgicheskoe proizvodstvo $\mathrm{v}$ strukture khozyaystvenno-kulturnykh modeley zapadnoy periferii alakulskoy kultury [Mining and Metallurgical Production in the Structure of Economic and Cultural Models of the Western Periphery of the Alakul Culture]. Uralskiy istoricheskiy vestnik [Ural Historical Bulletin], 2019, no. 1 (62), pp. 38-47. DOI: 10.30759/1728-9718-20191(62)-38-47.

29. Khokhlov A.A. Paleoantropologiya pogranichya lesostepi i stepi Volgo-Uralya $v$ epokhi neolita - bronzy: avtoref. dis. ... kand. ist. nauk [Paleoanthropology of the Bordering Forest-Steppe and Steppes of the Volga-Ural Region in the Neolithic - Bronze Age. Cand. hist. sci. abs. diss.]. Moscow, 1998. 23 p.

30. Khokhlov A.A. Kraniologicheskie materialy srubnoy kultury yuga Srednego Povolzhya [Craniological Materials of the Srubnaya Culture of the South of the Middle Volga Region]. Narody Rossii: ot proshlogo knastoyashchemu. V 2 ch. Ch. 2. Antropologiya: sb. nauch. st. [Peoples of Russia: From the Past to the Present. In 2 Parts. Part 2. Anthropology. Collection of Scientific Articles]. Moscow, Staryy Sad Publ., 2000, pp. 217-242.

31. Khokhlov A.A. Paleoantropologiya epokhi bronzy Samarskogo Povolzhya [Paleoanthropology of the Bronze Age of the Samara Volga Region]. Izvestiya Samarskogo nauchnogo tsentra RAN. Spets. vyp. "Istoriya Samarskogo Povolzhya s drevneyshikh vremen do nashikh dney. Bronzovyy vek» [Bulletin of the Samara Scientific Center of the Russian Academy of Sciences. Special. Issue "The History of the Samara Volga Region from Ancient Times to the Present Day. The Bronze Age], 2000, pp. 309-332.

32. Khokhlov A.A. Paleoantropologiya mogilnika srubnoy kultury Barinovka I [Paleoanthropology of the Burial Ground Barinovka I of the Srubnaya Culture]. Voprosy arkheologii Povolzhya: sb. nauch. st. [Issues of Archaeology of the Volga Region. Collection of Scientific Articles]. Samara, SamGPU, 2002, iss. 2, pp. 134-144.

33. Khokhlov A.A. Morfogeneticheskie protsessy $v$ Volgo-Uralye vepokhu rannego golotsena (po kraniologicheskim materialam mezolita bronzovogo veka) [Morphogenetic Processes in the Volga-Urals in the Era of the Early Holocene (Based on Craniological Materials of the Mesolithic-Bronze Age)]. Samara, SGSPU, 2017.368 p.

34. Khohlov A.A., Kitov E.P. Spetsifika antropologicheskogo sostava nositeley potapovosintashtinskikh kulturnykh traditsiy (po kraniologicheskim materialam Povolzhya i Urala perekhodnogo vremeni ot sredney k pozdney bronze) [The Specifics of the Anthropological Composition of the Carriers of Potapovo-Sintashta Cultural Traditions 
(Based on Craniological Materials of Transitional Periods from Middle to Late Bronze Ages from the Volga and Ural Regions)]. Protsess kulturogeneza nachalnoy pory pozdnego bronzovogo veka VolgoUralskogo regiona (voprosy khronologii, periodizatsii, istoriografii): materialy Mezhdunar. nauch. konf. (12-14 maya 2014 g.) [The Process of Cultural Genesis of the Initial Time of the Late Bronze Age from the Volga-Ural Region (Issues of Chronology, Periodization, Historiography). Proceedings of the International Scientific Conference (May 12-14, 2014)]. Samara, Izd-vo PGSGA, 2014, pp. 131-142.

35. Khokhlov A.A., Kitov E.P. Teoreticheskie i prakticheskie aspekty problemy proiskhozhdeniya fizicheskogo oblika nositeley kultur sintashtinskogo kruga pozdnego etapa epokhi bronzy [Theoretical and Practical Aspects of the Problem of the Origin of the Physical Appearance of Cultural Carriers of the Sintashta Circle of the Late Period of the Bronze Age]. Povolzhskaya arkheologiya [The Volga River Region Archaeology], 2019, no. 1 (27), pp. 59-71.

36. Chernykh E.N. Kargaly. Zabytyy mir [Kargaly. Forgotten World.]. Moscow, Nox, 1997. 177 p.

37. Chikisheva T.A. Dinamika antropologicheskoy differentsiatsii naseleniya yuga Zapadnoy Sibiri v epokhi neolita - rannego zheleza [Dynamics of Anthropological Differentiation of the Population of the South of Western Siberia in the Neolithic-Early Iron Age]. Novosibirsk, IAET SO RAN, 2012. 468 p.

38. Shevchenko A.V. Paleoantropologicheskie dannye $\mathrm{k}$ voprosu o proiskhozhdenii naseleniya srubnoy kulturno-istoricheskoy obshchnosti [Paleoanthropological Data on the Origin of the Population of the Srubnaya Culture and Historical Community]. Problemy antropologii drevnego $i$ sovremennogo naseleniya severa Evrazii: sb. nauch. st. [Problems of Anthropology of the Ancient and Modern Population of the North of Eurasia. Collection of Scientific Articles]. Leningrad, Nauka Publ., 1984, pp. 55-73.

39. Shevchenko A.V. Paleoantropologiya srubnikov Povolzhya V sravnitelno-antropologicheskom osveshchenii [Paleoanthropology of the Volga Region Srubnaya Culture in Comparative Anthropological Lighting]. Arkheologiya Rossii. Svod arkheologicheskikh istochnikov. T. 1. Pamyatniki srubnoy kultury. Volgo-Uralskoe mezhdurechye [Archaeology of Russia. Set of Archaeological Sources. Vol. 1. Sites of Srubnaya Culture. Volga-Ural Interfluve]. Saratov, Izd-vo Saratovskogo gosudarstvennogo universiteta, 1993, pp. 101-105.

40. Yusupov R.M. Antropologiya naseleniya srubnoy kultury Yuzhnogo Priuralya [Anthropology of the Srubnaya Population of the Southern Cis-Urals]. Materialy po epokhe bronzy $i$ rannego zheleza Yuzhnogo Priuralya i Nizhnego Povolzhya: sb. nauch. st. [Materials of the Bronze and Early Iron Age from the Southern Urals and Lower Volga. Collection of Scientific Articles]. Ufa, BNTs UrO AN SSSR, 1989, pp. 127-138.

41. Anthony D.W., Brown D.R., Khokhlov A.A., Kuznetsov P.F., Mochalov O.D. A Bronze Age Landscape in the Russian Steppes. The Samara Valley Project. Los Angeles, UCLA Cotsen Institute of Archaeology Press, 2016.513 p. DOI: 10.1017/aaq.2017.23.

42. Allentoft M.E. et al. Population Genomics of Bronse Age Eurasia. Nature, 2015, vol. 522, pp. 167172. DOI: $10.1038 /$ nature14507.

43. Narasimhan V. et all. The Formation of Human Populations in South and Central Asia. Science, 2019, vol.365, iss. 6457, eaat7487. DOI: 10.1126/science.aat7487.

\section{Information About the Authors}

Aleksandr A. Khokhlov, Doctor of Sciences (History), Professor, Department of Biology, Ecology and Training Methods, Head of the Volga-Ural Center for Paleoanthropological Studies, Samara State University of Social Sciences and Education, M. Gorkogo St, 65/67, 443099 Samara, Russian Federation, khokhlov_aa@mail.ru, https://orcid.org/0000-0003-0442-9616

Egor P. Kitov, Candidate of Sciences (History), Senior Researcher, Center of Anthropoecology, Institute of Ethnology and Anthropology RAS, Prosp. Leninskiy 32A, 119334 Moscow, Russian Federation, kadet_eg@mail.ru, https://orcid.org/0000-0002-0159-3288

Yulia O. Kapinus, Researcher, Volga-Ural Center for Paleoanthropological Studies, Samara State University of Social Sciences and Education, M. Gorkogo St, 65/67, 443099 Samara, Russian Federation, kapinusyulija@mail.ru,https://orcid.org/0000-0001-9627-0109

\section{Информация об авторах}

Александр Александрович Хохлов, доктор исторических наук, профессор кафедры биологии, экологии и методики обучения, заведующий Волго-Уральским центром палеоантрополо- 
гических исследований, Самарский государственный социально-педагогический университет, ул. М. Горького, 65/67, 443099 г. Самара, Российская Федерация, khokhlov_aa@mail.ru, https://orcid.org/0000-0003-0442-9616

Егор Петрович Китов, кандидат исторических наук, старший научный сотрудник Центра антропоэкологии, Институт этнологии и антропологии им. Н.Н. Миклухо-Маклая РАН, просп. Ленинский, 32А, 119334 г. Москва, Российская Федерация, kadet_eg@mail.ru, https://orcid.org/0000-0002-0159-3288

Юлия Олеговна Капинус, научный сотрудник Волго-Уральского центра палеоантропологических исследований, Самарский государственный социально-педагогический университет, ул. М. Горького, 65/67, 443099 г. Самара, Российская Федерация, kapinusyulija@mail.ru, https://orcid.org/0000-0001-9627-0109 